\title{
Cucullia tiefi Tshetverikov, 1956 (Insecta: Lepidoptera: Noctuidae): New data on the distribution
}

\author{
Sergey Titov ${ }^{1}$ and Anton Volynkin ${ }^{2 *}$ \\ 1 The Research Centre for Environmental “Monitoring”, Pavlodar State University, Lomova str. 64, KZ-140008, Pavlodar, Kazakhstan. \\ 2 Altai State University. Lenina str. 61. RF-656000. Barnaul, Russian Federation; Tigirek State Natural Reserve. Nikitina str. 111, office 42 . RF-6043. \\ Barnaul, Russian Federation. \\ * Corresponding author. E-mail: volynkin_a@mail.ru
}

ABSTRACT: A very rare little-known species Cucullia tiefi Tshetverikov, 1956 recorded in North-East Kazakhstan for the first time. The adults, male and female genitalia are illustrated. The structure of male vesica is discussed.

The genus Cucullia Schrank, 1802 belongs to the tribe Cucullini Herrich-Schäffer, 1850 of the subfamily Cucullinae. It is widely distributed in all continents except Australia and Antarctica. The Eurasian and North African taxa were recently revised (Ronkay and Ronkay 2009). The genus contains over 100 species in the Palaearctic Region. One of them - C. tiefi Tshetverikov was known by two specimens only and both were collected at the beginning of the 20th century. C. tiefi was described basing on a single male from South Ural (Orenburg) (Tshetverikov 1956). The second known specimen (female) was collected in North-West Kazakhstan (Uralsk) (Figure 1). The Lepidoptera fauna of South Ural and West Kazakhstan has been recently studied (Nupponen and Fibiger 2002, 2006; Gorbunov 2011), but C. tiefi was not found.
In contrast to the West Kazakhstan, the Lepidoptera fauna of North-East Kazakhstan was poorly studied. Starting from 2010, the senior author conducts an intensive faunistic study of the Macrolepidoptera fauna of North-East Kazakhstan. The field work is conducted from April to September every year. The night collecting is made by using mercury and UV light. In the spring 2012 two specimens of $C$. tiefi were collected in south-west Pavlodar Region (Figure 2). It is the first find of the species during the past 100 years.

Material examined: 1 male, 1 female, "19.iv.2012, NE Kazakhstan, Pavlodar area, Ekibastuz district, 10-12 km NW Shiderty, $51^{\circ} 48^{\prime}$ N, $7^{\circ} 35^{\prime}$ E, S.V. Titov leg." (the specimens are deposited in coll. Research Environment Centre "Monitoring", Pavlodar State University, Pavlodar,

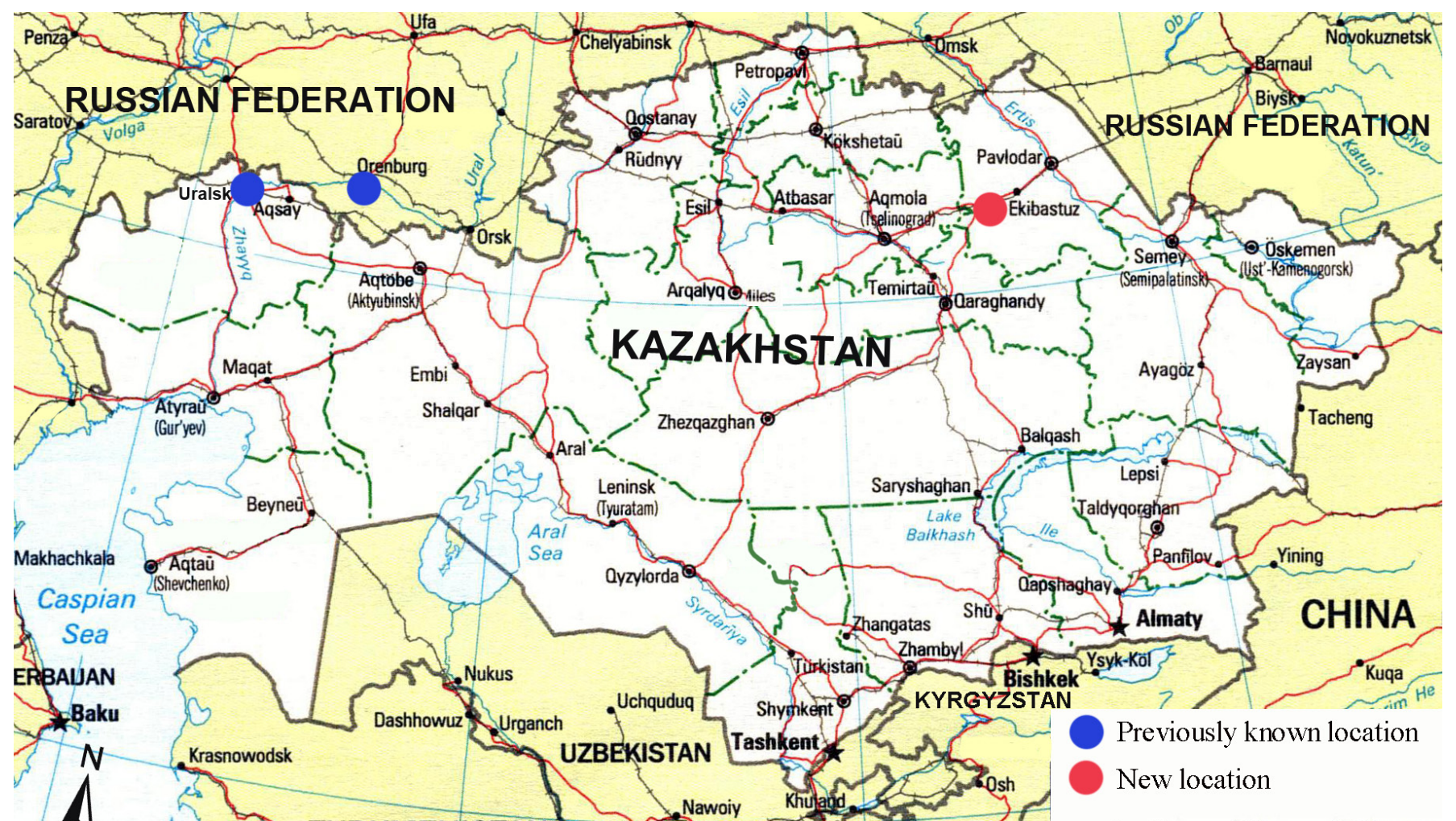

FigURE 1. Distribution map of Cucullia tiefi. 
Kazakhstan). Moths were collected using a mercury lamp trap. C. tiefi is a spring species, distributed in the flat steppe. Other species of Noctuidae found together with this species are as follows: Euclidia fortalitium (Tauscher, 1809), Cucullia inderiensis Herrich-Schäffer, 1856, Simyra nervosa ([Denis et Schiffermüller], 1775), $S$. dentinosa Freyer, 1838, Conistra vaccinii (Linnaeus, 1761), Xylena vetusta (Hübner, [1813]), Orthosia incerta (Hufnagel, 1766), Perigrapha circumducta (Lederer, 1855). The find of $C$. tiefi in North-East Kazakhstan was surprising. The collection site is distant from the other two known localities by up to $1500 \mathrm{~km}$ (Figure 1). It appears that this species is distributed in the steppes across the entire of Northern Kazakhstan.

Notes. The genitalia of both sexes (Figures 3 and 4) was described by Ronkay and Ronkay (2009). The aedeagus of the holotype has five large cornuti that is unique to the Palaearctic species of the genus. It is probable that the holotype is an aberrative specimen (L. Ronkay, pers. comm.). The male from NE Kazakhstan has only three cornuti, which is normal for the Cucullia generosa species group. Vesica consist of two diverticula armed with 3 cornuti and a large upturned sac terminating in a pointed tip; ductus ejaculatorius originate from the medial third of the sac.
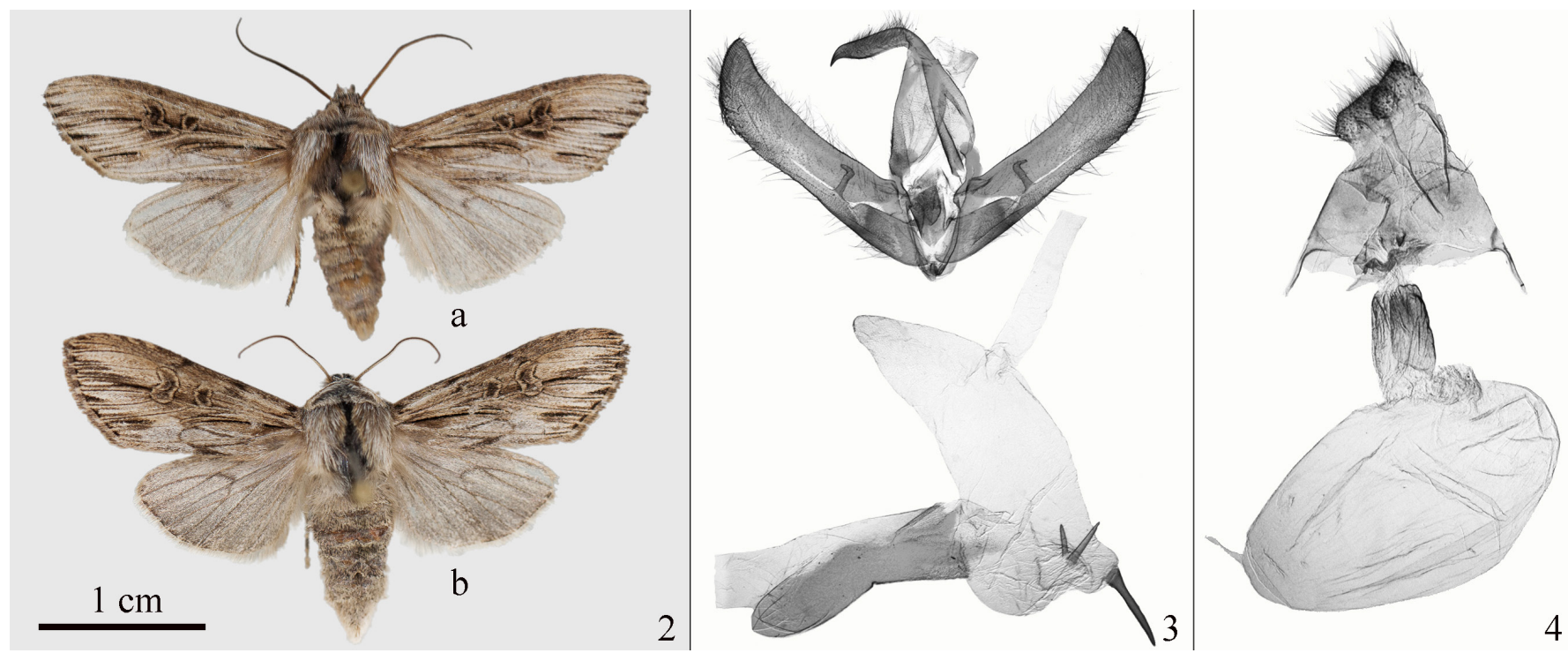

Figures 2-4. Cucullia tiefi, adults and genitalia: 2) adults, NE Kazakhstan: a - male, b - female; 3) male genitalia, NE Kazakhstan, slide AV0751 Volynkin; 4) female genitalia, NE Kazakhstan, slide AV0757 Volynkin.

ACKNOWLEDGMenTs: We thank Dr. László Ronkay (Hungarian Natural History Museum, Budapest, Hungary) and Dr. Alexej Matov (Zoological Institute Russian Academy of Sciences, St. Petersburg, Russia) for valuable consultations.

\section{Literature Cited}

Gorbunov, P. 2011. Macrolepidoptera of deserts and the southern steppes of West Kazakhstan. Ekaterinburg: Lisitsyna. 192 p (in Russian).

Nupponen, K. and M. Fibiger, 2002. Contribution to the fauna of Bombyces, Sphinges and Noctuidae of the Southern Ural Mountains, with description of Dichagyris lux Fibiger \& K. Nupponen, sp. n. (Lepidoptera: Lasiocampidae, Endromidae, Saturniidae, Sphingidae, Notodontidae, Noctuidae, Pantheidae, Lymantriidae, Nolidae, Arctiidae). Phegea 30(4): 121-185.

Nupponen, K. and M. Fibiger, 2006. Additions and corrections to the list of Bombyces, Sphinges and Noctuidae of the Southern Ural Mountains.
Part I. (Lepidoptera: Lasiocampidae, Lemoniidae, Sphingidae, Notodontidae, Noctuidae, Pantheidae, Lymantriidae, Nolidae, Arctiidae). Esperiana 12: 167-195.

Ronkay, G. and L. Ronkay, 2009. Cucullinae 1. A Taxonomic Atlas of the Eurasian and North African Noctuoidea. Vol. 2. Budapest: Heterocera press. 365 p.

Tshetverikov, S. 1956. New species of the genus Cucullia Schrk. (Lepidoptera, Noctuidae). Entomologicheskoe Obozrenie 35: 927-928 (in Russian).

RECEIVED: February 2013

ACCEPTED: August 2013

Published online: August 2013

EDITORIAL RESPONSIBILITY: Cristiano Agra Iserhard 